\title{
MANUAL TRAINING IN THE CONTEXT OF PRESCHOOL CURRICULUM
}

\author{
Eva ŠMELOV $\boldsymbol{A}^{*}$, Univerzita Palackého v Olomouci
}

Přijato: 16. 5. 2015 / Akceptováno: 19. 6. 2015

Typ článku: Teoretická studie

DOI: $10.5507 /$ jtie.2015.010

Abstract: In her theoretical study, the author performed an analysis of educational programs for kindergartens that have been developed since 1945. In terms of the objectives and content of preschool education the author focuses on manual training, which had been, until 1990, included in the compulsory educational content as one of the components of education. In 2001 preschool teachers were presented with a completely different curriculum and also a new concept of educational areas, which included polytechnic education not as a component of education but in the form of knowledge, skills and attitudes contained in all educational areas. Based on the predetermined criteria the author monitored the basic differences in manual training during socialist education and in the context of the current preschool curriculum.

Key words: Child, kindergarten, educational program, polytechnic education.

\section{PRACOVNÍ VÝCHOVA V KONTEXTU VÝVOJE PŘEDŠKOLNÍHO KURIKULA}

Resumé: Autorka v rámci teoretické studie provádí analýzu vzdělávacích programů pro mateřské školy, které vznikaly od roku 1945 po současnost. Z hlediska cílů a obsahu předškolniho vzdělávání se zaměřruje na pracovní výchovu, která do roku 1990 byla součástí povinného vzdělávacího obsahu jako jedna z výchovných složek. V roce 2001 se předškolní pedagogové seznamují se zcela odlišným kurikulem, a tím i s novým pojetím vzdělávacích oblastí, jejichž součástí je polytechnické vzdělávání, a to již ne jako složka výchovy, ale v podobě vědomostí, dovedností a postojů. Na základě stanovených kritérií autorka sleduje zásadni rozdíly $v$ pojetí pracovni výchovy $v$ období socialistického školství a v pojetí současného předškolního kurikula.

Klíčová slova: dítě, mateřská škola, vzdělávací program, polytechnická výchova.

*Autor pro korespondenci: eva.smelova@upol.cz 


\section{1 Úvod}

Předškolní kurikulum prošlo svým mnohaletým vývojem. V období socialistického školství bylo základem sociocentrické zaměření, které se po roce 1990 postupně s demokratizací školství vyvíjí a přechází v osobnostně orientované pojetí, což se odrazilo i do celkové koncepce předškolního kurikula, tedy i do všech vzdělávacích oblastí. V současné době se ukazuje jako nezbytné posílit zejména polytechnické vzdělávání, v období socialismu nazývané jako pracovní výchova, a to již od předškolního věku. V rámci polytechnického vzdělávání by měly být dětem zprostředkovávány elementární vědomosti z oblasti technických oborů a rozvíjeny základní dovednosti jako předstupeň všeobecně technických dovedností.

\section{Exkurz do historie pracovní výchovy}

Požadavky a cíle výchovy tedy i pracovní je nutné chápat $\mathrm{v}$ kontextu charakteru dané společnosti, v níž byla uskutečňovaná. $\mathrm{V}$ prvobytně pospolné společnosti neexistovaly trrídní rozdíly mezi dospělými, nelišila se ani výchova dětí. Základem výchovy bylo předávání zkušeností rodičủ z generace na generaci. Osvojení si pracovních dovedností a návyků byly základem $\mathrm{k}$ zajištění životních potřeb, kde lze spatřovat počátky vzniku pracovní výchovy. Jakmile začala být činnost dospělých členěna na práci pro muže a pro ženy, dochází $\mathrm{k}$ diferenciaci výchovy chlapců a dívek. Výchova na tomto stupni společenského vývoje byla úzce vázaná na život ve společnosti, můžeme hovořit o prvním př́kladu všestranné výchovy dětí, v níž pracovní výchova zaujímala své významné místo.

Starověká třídní společnost přináší nový pohled na pracovní výchovu. Manuální práce je vyloučena ze života vládnoucí vrstvy, tedy i pracovní výchova, ta je určena výhradně nesvobodným. Odlišuje se cíl výchovy pro vládnoucí tř́du a pro nesvobodné a otroky. Obsahem výchovy vládnoucí vrstvy byla výchova $\mathrm{k}$ tělesné zdatnosti, duchovní čistotě vyspělosti. Vyvrcholení tohoto pojetí lze spatřovat $\mathrm{v}$ řeckém ideálu harmonickému prolínání složek tělesné a duchovní krásy.

Po staletí, v období středověku, za feudalismu byli na výchovu k fyzické práci připravováni nadále nesvobodní. Otec vychovával syna pro práci, kterou sám vykonával. Matka učila dceru domácím pracím, které souvisely s péčí o rodinu.

Nový př́stup $\mathrm{k}$ pracovní výchově se objevuje $\mathrm{v}$ souvislosti s nově zřizovanými cechovními školami, a to jako reakce nespokojených řemeslníků a kupců s církevními školami dožívajícího feudalismu. Řemeslníci začali přijímat do učení mladé pomocníky, které zaškolovali. Můžeme zde hovořit o novém př́stupu $\mathrm{k}$ „profesionální“ př́ípravě mladých lidí na budoucí povolání.

Rozvoj výrobních prostředků, zostřování vnitřních sociálních rozporů mezi ožívajícím feudalismem a raným kapitalismem vedly ve středověku ke kritice scholastické výchovy. Do popředí vystupují nové prvky ve výchově, které ovlivnily i výchovu pracovní, a to i v předškolním věku. Význam pracovní výchovy zdůrazňovali např. J. A. Komenský, J. Locke, J. J. Rousseau, J. H. Pestalozzi.

J. A. Komenský (1592-1670) formuloval cíle první výchovy a vzdělávání: „aby člověk i důstojnost obrazu božího v sobě znal i důstojnosti jeho ostř́ihal a hájil.“ Cíl konkretizoval do jednotlivých výchovných složek, jejichž součástí je i výchova manuální. V Informatoriu školy mateřské Komenský uvádí, co by mělo být obsahem cvičení v manuálních dovednostech a v řeči. Cvičení „v činech a pracech“ obsahuje činnosti a manuální dovednosti, které jsou propojené s rozvojem rozumových schopností. 
Vedle mechaniky jako vědního základu manuální obratnosti zařazuje dialektiku jako základ správného posuzování a nejjednodušší operace týkající se měření a počitání. Dále sem řadí kreslení, psaní, zpěv, hru na hudební nástroj, učení se říkankám a vyprávění. (J.A. Komenský, 2007)

Na dalším stupni věkového vzdělávání nazývá Komenský tento oddíl „ars“, uměním, což představovalo dovednost, získanou schopnost, jak správně ovládat různé věci, jak řešit problémy ve shodě $\mathrm{s}$ přirozeností (věcí a lidí). Práci zde nechápe v pravém slova smyslu, ale jako snahu vytvořit vlastní dovedností určité věci, tedy cílevědomou činností. Cvičení v činnostech v Komenského pojetí obsahuje podchycení dětské činorodosti, a to jaké úvod k pozdější pracovní výchově. (Čapková, D. 1980, s. 77-78)

J. J. Rouseau (1712-1778) zdůrazňuje význam fyzické práce pro starší děti. Odmítá předsudek, že manuální práce je nečistá. Podle Rousseaua je hodina práce př́nosnějš́í nežli celodenní učení. Za pokrokové lze považovat jeho požadavek sbližování dítěte $\mathrm{s}$ pracovním prostředím. Práci chápal jako prostředek, který člověku umožňuje stát se nezávislým, dává mu široký duševní rozhled a schopnost chápat společenské vztahy. (In Šmelová, 200č)

Představitelé osvícenství a počátků průmyslové revoluce věnovali značnou pozornost výchově $\mathrm{k}$ práci. Pro období předškolního věku to znamenalo zejména správné pojetí činností, které $\mathrm{k}$ tomuto věku zcela neodmyslitelně patři, což je hra. Hra byla chápána jako prostředek k osobnostnímu rozvoji dítěte po stránce fyzické, psychické i pracovní. Pozitivní př́stup $\mathrm{k}$ pracovním činnostem tvořil součást mravní výchovy jako př́pravy pro práci $\mathrm{v}$ zemědělství, $\mathrm{v}$ továrně, $\mathrm{v}$ domácnosti apod. Tvořila součást návrhů pro výchovu, a to $\mathrm{s}$ cílem rozvoje dětské přirozenosti. (např. Pestalozzi, Owen)

Rozvoj průmyslu v 19. a 20. století kladl vyšší nároky na př́ípravu dělníkủ. Fyzická práce se tak stala nedílnou součástí výchovy a vzdělávání. Uvedenou skutečnost lze spatřovat např́íklad $\mathrm{v}$ př́rodovědných předmětech, které byly výrazně zastoupeny ve školní výuce zejména na konci 19. století. Výroba potřebovala dělníky s určitou mírou znalostí z oblasti nejenom prírodních věd, ale i věd technických.

Po rozpadu Rakouska-Uherska vystupuje intenzivně do popředí požadavek začlenění manuálních prací do škol. V roce 1919 byly zavedeny výnosem ministerstva školství a národní osvěty, a to na zkoušku do obecných a měštanských škol.

\section{Pracovní výchova jako součást předškolního kurikula}

3. 1 Výchovně vzdělávací osnovy (1945-1960)

Počátkem 20. století pod vlivem reformních snah si předškolní instituce vytvářely vlastní plány a programy, neexistovaly závazné vzdělávací dokumenty pro předškolní vzdělávání. Snahou bylo odstranění školského rázu z mateřských škol, důraz byl kladený na přirozený vývoj dítěte s respektováním jeho zájmů a potřeb. Po druhé světové válce se zavedením jednotného školského systému, v několika etapách, vznikaly osnovy a programy pro mateřské školy, již jako normativní dokumenty. Důraz byl kladený na prípravu dítěte na školu. Lze konstatovat, že výchovné programy byly velmi dobře rozpracované, nedostatkem bylo jejich ideologické pojetí.

Stále více do popředí vystupovala nutnost respektovat u dětí individuální i věkové zvláštnosti a potřeby dítěte. I když byl obsah vzdělávání uspořádaný podle věku dětí, závazné programy, přetížené učivem a realizované zejména jako povinná zaměstnání, nevytvářely pro dítě optimální podmínky. Poslední program z roku 1984 ztratil svoji závaznou platnost $\mathrm{v}$ roce 1989 . Učitelky odmítly pracovat podle uvedeného programu $\mathrm{z}$ 
roku 1984. Začaly vytvářet vlastní plány vzdělávání, inspiraci hledaly v různých alternativních programech.

Léta 1945-1948 byla obdobím intenzivního rozvoje mateřských škol. Z praxe vyvstal požadavek vydat celostátně závazné osnovy. Pedagogické dokumenty měly vnést do výchovné práce mateřských škol systém a cílevědomost. Ministerstvo školství vydalo $\mathrm{v}$ roce 1945 Prozatímní pracovní program pro mateřské školy. Jehož východiskem byly osnovy z roku 1938, byly zpracované v duchu reformních myšlenek první republiky. Dokument představoval první celostátní směrnici pro výchovnou práci $\mathrm{s}$ dětmi $\mathrm{v}$ předškolních zařízeních. $\mathrm{V}$ tomto roce byl také vydaný spis Jarmily Šukalové Mateřská škola, který předkládal učitelkám náměty pro jejich práci s dětmi.

V roce 1948 byl vydaný nový Pracovní program pro mateřské školy, který napomohl k částečnému usměrnění a systematičnosti výchovné práce. Obsah byl poprvé uspořádaný do výchovných složek. Pracovní program posílil zejména kolektivní řízené činnosti. Po roce 1948 začaly do systému výchovné práce v mateřských školách pronikat zkušenosti práce sovětských dětských sadů. Činnost našich mateřských škol byla silně pod vlivem sovětské pedagogiky. Důraz byl kladený zejména na mravní výchovu, výchovu ke kolektivismu.

Období let 1948-1960 bylo zaměřeno na prohloubení socialistického charakteru předškolní výchovy. V roce 1953 byly na těchto principech zpracovány Prozatímní osnovy pro mateřské školy. Osnovy představovaly první závaznou normu pro práci všech československých mateřských škol. V osnovách byl stanoven rozsah poznatků, dovedností a návyků pro dvě věkové skupiny, a to děti mladší a starší. Jednalo se o pevně stanovené výchovné požadavky. Obsah výchovné práce byl rozčleněný do jednotlivých výchovných složek. Došlo k posílení didaktické funkce, což se v práci mateřských škol negativně odrazilo. Učitelky soustředily svoji pozornost zejména na rozumovou složku. Docházelo $\mathrm{k}$ opomíjení významu hry. Základ učitelky spatřovaly $\mathrm{v}$ povinných zaměstnáních. Potíže jim činil výběr úkolů, často docházelo $\mathrm{k}$ nezdravému přetěžování dětí. Při plánování práce se nedařilo respektovat zásadu soustavnosti a přiměřenosti. Převládaly zejména metody verbální. Praxe ukazovala i na další potíže spojené s prací podle osnov, které byly přetížené učivem.

V roce 1955 byly vydány Osnovy pro mateřské školy. Osnovy byly doplněny o stručné metodické pokyny, které měly být vodítkem při plánování a plnění vytýčených úkolů, při řízení her a ostatních denních činností. Př́nos těchto osnov můžeme spatřovat např. ve zdůrazňovaném významu hry. Pro posílení výchovného aspektu byla včleněna kapitola Spolupráce mateřské školy s rodinou. Učitelky soustředily svoji pozornost na zaměstnání jako na závaznou formu práce a zaměřovaly se tak zejména na řízené činnosti. Uvedený problém vyplýval i z koncepce samotných osnov, které strukturou výchovných složek připomínaly systém školních vyučovacích předmětů.

Ideologické pojetí výchovy mělo $\mathrm{v}$ druhé polovině 20 . století slábnoucí tendenci. V roce 1958 byly vydané Pokusné osnovy pro mateřské školy. K osnovám byla zpracována príručka Rok v mateřské škole (1960), která obsahovala řadu námětů pro práci s dětmi. (Po roce 1989 hledalo mnoho učitelek inspiraci právě v této příručce).(Šmelová, 2004) 


\section{2 Osnovy a programy výchovné práce pro mateřské školy (1960 - 1989$)$}

V roce 1960 byly vydány Osnovy výchovné práce pro mateřské školy. Rámcově vymezovaly cíle a vlastní obsah výchovné práce. Učitelkám dávaly větší prostor pro plánování práce s větší možností respektovat věkové zvláštnosti dětí.

Úkolem mateřské školy byl všestranný rozvoj osobnosti dítěte na úseku výchovy tělesné, rozumové, mravní, pracovní a estetické. Všechny složky jsou považovány za důležité a mají rovnocenné místo. $\mathrm{V}$ rámci výchovně vzdělávacího procesu má být zajištěno jejich prolínání. Pracovní výchova byla úzce propojena s výchovou mravní. Děti si měly při činnostech aktivně osvojovat pracovní zkušenosti, dovednosti a návyky. Měly se seznámit $\mathrm{v}$ přiměřených podmínkách s prací dospělých a získávat $\mathrm{k}$ práci kladný vztah.

Pracovní výchova

„V pracovní výchově v předškolním věku využivá učitelka dètské aktivity $k$ tomu, aby dèti v přirozených situacích, při činnostech, o kterou maji dèti zájem a která je přiměřená jejich věku, ziskávaly cenné zkušenosti, poznatky a dovednosti, na kterých může později budovat škola všeobecně vzdèlávací; některé z nich se stanou základem trvalých vlastností osobnosti. Pracovni výchova neznamená jen vytváreni pracovnich dovedností, ale je součástí všestranného výchovného působení. Správně organizovaná práce je prostředek výchovy mravní (samostatnost, ukázněnost, vzájemná pomoc, kolektivnost, smysl pro pořádek, správný pomèr ke společenskému vlastnictví, úcta k pracujicím), rozumové (obohacuje o poznání jevů v prírodě $i$ ve společnosti, vyžaduje pozornost, učí poznávat některé hodnoty, přmýšlet o postupu a výsledku pracovních činností, dává konkrétni predstavy, pomáhá vývoji dětské reči tím, že dèti mohou mezi sebou hovořit, obraceji se $k$ dospělým). Přispivá $k$ tělesnému rozvoji organismu, rozviji pohybové schopnosti, pomáhá zdokonalovat smyslové orgány a dètský organismus utužuje. “

Pracovní výchova byla členěna do tří okruhů:

- $\quad$ sebeobsluha: $\mathrm{v}$ šatně, $\mathrm{v}$ umývárně, při stolování, při odpočinku, ve třídě,

- práce na zahradě a $\mathrm{v}$ koutku živé prírody,

- zacházení s nástroji a s materiálem.

Obsah pracovní výchovy (1960)

\section{SEBEOBSLUHA}

\section{Mladší děti}

Učí se obléknout, uložit oblečení na značku, zout a obout obuv, uložit boty, samostatně si umýt ruce, svléknout spodní prádlo bez rozepínání, zacházet správně se splachovacím zařízením, používat toaletní papír, správně zacházet $\mathrm{s}$ nádobím, uklízet stůl po přesnídávce, ukládat oděv na dané místo, urovnat pokrývku, židličky, uklidit hračky

\section{Starší děti}

Učí se oblékat a svlékat všechny části oděvu, uložit je na místo, obouvat a zouvat se, vázat tkaničku, zapínat zip, uložit boty do poličky, sáčku. Uvedené činnosti konat pro sebe, ale i při pomoci mladším dětem. Dále jsou děti vedeny k samostatnosti při osobní hygieně, při oblékání, stolování. Učí se používat příbor, uklidit stůl po stolování, podílet se na úklidu lůžkovin, zvládnou zapínání a rozepínání knoflíků u lůžkovin. Opatrně zacházejí s nábytkem, uklízí hračky, rovnají knihy do poličky, převlékají loutky apod. Pomáhají při př́ipravě materiálu na zaměstnání. 


\section{PRÁCE NA ZAHRADĚ A V KOUTKU ŽIVÉ PŘíRODY \\ Mladší děti}

Při hrách $\mathrm{s}$ pískem a se sněhem se děti učí používat lopatky, kbelíčky, tvořítka. Sbírají kamínky, plody, lístky. Sbírají listí, pomáhají při sklizni ovoce.

\section{Starší děti}

Správně používají lopatky, kbelíčky, tvořítek při hrách s pískem a se sněhem. Tvoří jednoduché stavby z písku, ze sněhu, převážejí sníh. Učí se správně použivat krabičky, motyčky, konévky. Sbírají kaménky, plody, semena, listí. Pečují o rostliny, kypř́i a urovnávají půdu, pomáhají při setí, sázení a zalévání, shrabují a odvážejí listí. Uhrabují cestičky, uklízejí zahradu. Pomáhají při sklizni zeleniny a ovoce. Pečují o zviŕata pomáhají při krmení. Starají se o koutek živé přírody (rostliny, akvárium).

\section{ZACHÁZENÍ S NÁSTROJI A S MATERIÁLEM \\ Mladší děti}

Učí se zacházet s konstruktivními stavebnicemi, vytrhávají z papíru (sněhové vločky, uhlí), prèekládají papír na polovinu.

\section{Starší děti}

Děti vytrhávají a nalepují papír s použitím lepidla, překládají papír podle úhlopříčky, po naznačené čáře i bez vyznačení, samostatně skládají a tvoří z papíru, přestřihují proužky papíru po naznačené čáře, učí se správně zacházet $\mathrm{s}$ nůžkami při výrobě jednoduchých hraček z papíru, korku, látky apod. Pomáhají při úpravě nástěnky. Učí se dotloukat hřebíky, vyrábějí jednoduché hračky (letadlo, auto). Získané dovednosti uplatňují při plnění úlohy hospodářu $\mathrm{k}$ práci pro celý kolektiv. Do popředí vystupuje kolektivní stránka výchovného procesu, odpovědnost, radost z práce pro celek a z pomoci dospělým.

Z důvodu zajištění všestranného rozvoje každého dítěte si učitelka vlastní výchovnou práci plánovala. $\mathrm{V}$ písemných prípravách promýšlela obsah, postup, metody a organizaci s ohledem na jejich věk. Současně sledovala dosažené výsledky.

Učitelka vytvářela výchovné plány, jejichž východiskem byly výchovné osnovy pro danou věkovou skupinu. Úkoly konkretizovala s přihlédnutím $\mathrm{k}$ věku dětí, $\mathrm{k}$ podmínkám zařízení. Současně promýšlela, kdy a jakým způsobem aktivity budou realizované. Mimo rámcového plánu na delší časové období, si učitelky vypracovávaly denní př́ípravu. V průběhu jednoho až dvou týdnů vystřídala učitelka všechny složky výchovy. Z pracovních činností zařazovala občas do zaměstnání práci s papírem. Úkoly pracovní výchovy plnila nejenom $\mathrm{v}$ ř́zených zaměstnáních, ale i v rámci přechodových činností, při volných hrách i ostatních denních činnostech. Obsahem odpoledních zábavných činností byli zejména konstruktivní činnosti, práce s př́rodninami, modelování, práce $\mathrm{v}$ koutku živé prírody apod. (Osnovy výchovné práce, 1961).

V roce 1963 byly vydány Osnovy výchovné práce pro jesle a mateřské školy. Východiskem byly osnovy z roku 1958 a 1960 . Obsah výchovy byl nadále rozpracovaný podle jednotlivých výchovných složek a do dvou věkových skupin pro období 3-5let a období 5-6let dítěte.

$\mathrm{V}$ osnovách se hovořilo o potřebě respektovat věkové a individuální zvláštnosti dítěte. Množství stanovených úkolů, ale nevytvářelo prostor pro změnu $\mathrm{v}$ př́istupu $\mathrm{k}$ dítěti, nebot' úkoly učitelky pojímaly jako dogma. Osnovy byly platné až do roku 1967. 
Od tohoto roku končí období osnov v mateřských školách. Pojem osnovy byl narazený pojmem program. Tímto mělo dojít k odlišení mateřské školy od školy základní, nebot' ta pracovala podle osnov.

V roce 1967 vstoupily v platnost nové normativní směrnice určené pro výchovu děti od narození do šesti let Program výchovné práce v jeslích a mateřských školách. Osou programu bylo členění do dvou skupin, a to pro děti do tř́i let a děti ve věku od tř́ do šesti let. Obsah byl členěn podle výchovných složek. Se snahou vytvořit co nejpropracovanější program došlo ke značnému prétížení programu učivem. Učitelky měly před sebou dokument, který je velmi svazoval a nevytvárel podmínky pro tvořivou práci. Současně $\mathrm{s}$ programem byla vydána Metodika výchovné práce $\mathrm{v}$ jeslích a mateřských školách. Metodická část byla rozpracována do dvou hlavních okruhů, pro jesle a mateřskou školu. Další vnitřní členění bylo učiněno na základě věku dětí. Výchovný obsah byl tradičně rozpracovaný podle složek výchovy. Děti v mateřské škole měly prostor pro hry dle vlastní volby $\mathrm{v}$ době ranního scházení. Ranní hry měly směřovat $\mathrm{k}$ vytváření pozitivních vztahů ve skupině. Zaměstnání byla realizována jako řízená činnost, které se účastnily všechny děti. Měla nejenom rozvíjet poznatky dětí, ale vést děti k sebeovládání, respektování druhých, soustředit se na činnost apod. Hry a zábavy byly realizované odpoledne $\mathrm{v}$ době po odpočinku a svačině. Náplň tvořily oblíbené činnosti dětí. Učitelky rozvíjely hru $\mathrm{v}$ menších $\mathrm{i}$ větších skupinách, zařazovány byly $\mathrm{i}$ činnosti, kterých se účastnily všechny děti společně. Hry a zábavy neměly mít ráz zaměstnání a učitelka nezařazovala do těchto činností zcela nové věci, přesto se jednalo o činnosti, které nevyplývaly $\mathrm{z}$ toho, co si dítě přeje dělat, ale $\mathrm{z}$ toho, co je pro děti připravené.

Pracovní výchova se nadále zaměřovala na oblast sebeobsluhy, na práci na zahradě a v koutku živé př́rody a na zacházení s nástroji a s materiálem.

Důraz byl kladený na vhodný rozmanitý výběr her se stavebním materiálem. Pro rozvoj tvořivosti byly využívány barevné mozaiky, tyčinky různé velikosti, korále, které bylo možné ukládat podle jednoduché předlohy, či navlékat podle vlastního záměru. Činnosti s papírem byly realizovány formou zaměstnání. Děti byly učeny překládat papír podle pokynů a předlohy, učily se papír nalepovat na papírové pásy apod. Vyráběly si elementární hračky a doplňky ke hrám napřr. vozík z krabiček, domečky. Cílem byl rozvoj technických zájmů a schopností dětí. V oblibě byly i sezónní činnosti, a to hry s pískem, s vodou, $\mathrm{v}$ zimě hry se sněhem, vytváření rozmanitých tvarů z ledu apod.

Propracování nové koncepce předškolní výchovy bylo základním úkolem, který měl být splněn do roku 1975. S cílem zajistit obsahovou návaznost a organickou předřazenost základní školy.

V roce 1978 byl vydán Program výchovné práce pro jesle a mateřské školy, k němuž byla vydaná a dvoudílná Metodika výchovné práce v předškolních zařízeních I. - jesle; Metodika výchovné práce $\mathrm{v}$ předškolních zařízeních II. - mateřské školy.

Program výchovné práce byl členěn opět na část určenou pro jesle a část určenou mateřské škole. Obsah byl tradičně koncipován podle složek výchovy, dále byl rozpracovaný podle věku dětí.

Základním prostředkem byla hra, učení, práce, zábava a slavnost. Hra byla pojímána jako základní činnost dítěte předškolního věku. Měla být využívána systematicky jako výchovný prostředek. Tě̌̌ištěm učení bylo opět řízené zaměstnání, které představovalo základní formu organizovaného kolektivního učení. Prostř̌ednictvím přiměřené práce měl být zajištěný zejména mravní rozvoj dětí. Zábavy a slavnosti byly prostředkem mravní 
výchovy, s cílem vytvářet a formovat vzájemné vztahy a vztahy ke společnosti, s důrazem na ideově společenské a estetické působení.

Úkolem pracovní výchovy bylo pravidelně děti vést $\mathrm{k}$ práci, navykat je na kontinuitní pracovní aktivitu, rozvíjet a vytvářet přiměřené pracovní představy, poznatky a dovednosti, jakož i kladné postoje $\mathrm{k}$ práci. Dítě mělo být poučováno o společenském a osobním významu práce. $\mathrm{V}$ rámci pracovní výchovy měly učitelky rozvíjet poznávací procesy dítěte, zejména prostřednictvím pozorováním objekti̊ $\mathrm{v}$ přírodě a ve společnosti, dále rozvíjet elementární pracovní a technické myšlení a představování. Práce měla být prostředkem $\mathrm{k}$ učení se cílevědomosti, koncentraci, pozornosti, sebekontroly a sebeovládání, dále vůli, schopnost překonávat překážky, morální i estetické vlastnosti.(1977) Úkoly byly rozpracovány podle věkových skupin (3-4, 4-5, 5-6), zaměřených na sebeobsluhu, na úklidové práce, na práci s technickým materiálem (papír, textil, hlína, písek), na práce pěstitelské a chovatelské. Pro děti 5-6 byla zařazena veřejně prospěšná práce.

Práce $\mathrm{s}$ technickým materiálem zahrnovala práci $\mathrm{s}$ papírem a textilem, práci $\mathrm{s}$ dřevěným materiálem a s př́rodninami, práce s kovovým materiálem, s pískem, hlínou a plastelínou.

Tab. 1 Obsah technických činností OBSAH TECHNICKÝCH ČINNOSTI PRO 5-6LETÉ DĚTI

Práce s papírem a s textilem: stř́hání, ohýbání, lepení, sestavování jednoduchých domků, měst, vagónů apod.

Práce s dř̌evěným materiálem a př́rodninami: práce se žaludy, kaštany, šiškami, špejlemi, hranoly, nosníky, práce s kladívkem, zatloukání hřebíků, zhotovování doplňků pro hry apod.

Práce s kovovým materiálem: práce s měkkým, tenkým drátem, s hliníkovou fólií.

Práce s pískem, hlínou, plastelínou: modelování, využívání špachtlí, lopatiček, prkének na hlazení, sušení hlíny apod.

Postupně byly zpracovávány metodické príručky pro jednotlivé složky výchovy. V roce 1984 byl vydaný Program výchovné práce pro jesle a mateřské školy. Program byl doplněný do roku 1988 o metodické příručky. Základním výchovným prostředkem byla hra, učení, práce a zábavné činnosti. Nově se objevují rekreační činnosti, které ve své podstatě jsou pouze novým označením pro zábavu a slavnosti. Pracovní výchova byla $\mathrm{v}$ podstatě stejně nastavena jako v předchozím programu.

Obsahem pracovní výchovy byly následující okruhy prací:

- Sebeobslužné práce, péče o vlastni osobu, péče o oděv, čistotu a stolování.

- Úklidové práce, pomoc ve škole.

- Práce stechnickým materiálem, práce spapírem, tkaninou, shlínou, s prírodními materiály, se dřevem a kovem.

- Práce pěstitelské, chovatelské v koutku živé přirody a na školní zahradè.

- Práce veřejně prospěšná.

- Vycházky s pracovně orientačním zaměrením.(1988)

Velmi podrobně rozpracovaný program nepřinesl př́liš pozitivního do praxe škol. Velké množství úkolů, které učitelky musely s dětmi plnit, vedl $\mathrm{k}$ nespokojenosti učitelek, které pracovaly pod neustálým časovým tlakem. Docházelo k přetěžování dětí. 
Práce na mateřských školách byla přeorganizovaná, dětem bylo dáno velmi málo času pro spontánní tvořivou činnost.

Tab. 2 Přehled osnov a programů v letech 1945 - 1989

\begin{tabular}{|l|l|}
\hline 1945 & Prozatímní pracovní program pro MŠ \\
\hline 1948 & Pracovní program pro MŠ \\
\hline 1953 & Prozatímní osnovy pro MŠ \\
\hline 1955 & Osnovy pro MŠ \\
\hline 1958 & Pokusné osnovy pro MŠ \\
\hline 1960 & Osnovy výchovné práce pro MŠ \\
\hline 1963 & Osnovy výchovné práce pro jesle a MŠ \\
\hline 1967 & Program výchovné práce v jeslích a MŠ \\
\hline 1978 & Program výchovné práce pro jesle a MŠ \\
\hline 1984 & Program výchovné práce pro jesle a MŠ \\
\hline
\end{tabular}

Pracovní výchova byla postupně v rámci vývoje předškolního kurikula rozpracovávaná. Byla jí věnovaná stále větší pozornost. $V$ rámci výchovných složek měla rovnocenné postavení a prolínala všemi výchovnými složkami.

\section{Polytechnické vzdělávání jako součást Rámcového vzdělávacího programu pro předškolní vzdělávání}

Od roku 1990 přestal být program výchovné práce závazným kurikulem. Učitelky využívaly pro tvorbu plánů různé metodické materiály, nechaly se inspirovat alternativními programy apod. V roce 2001 byla vytvořena první pokusná verze Rámcového vzdělávacího programu pro předškolní vzdělávání (dále RVP PV). Tento program byl od roku 2005 platným kurikulem, od záŕí roku 2007 se stal kurikulem závazným.

RVP PV představuje zcela odlišné kurikulum od předchozích vzdělávacích osnov a programů. Požadované výstupy nejsou již specifikované podle věkových skupin, ale do podoby klíčových kompetencí a očekávaných výstupů, kterých má dítě dosáhnout podle svých možností na konci předškolního vzdělávání. Složky výchov nahradilo pět výchovných oblastí: Dítě a jeho tělo, Dítě a psychika, Dítě a ten druhý, Ditě a společnost, Ditě a svět, v rámci nichž jsou výchovné složky zakomponované.

Učitelky plánují svoji práci, v níž se musí všechny oblasti prolínat. V oblasti Dítě a jeho tělo jsou očekávané výstupy, které jsou zaměřeny zejména na rozvoj sebeobsluhy a práci materiálem např::

- ovládat koordinaci ruky a oka, zvládat jemnou motoriku (zacházet s předměty denní potřeby, sdrobnými pomůckami, s nástroji, náčiním a materiálem, zacházet $\mathrm{s}$ grafickým a výtvarným materiálem, např. $\mathrm{s}$ tužkami, barvami, nůžkami, papírem, modelovací hmotou, zacházet s jednoduchými hudebními nástroji apod.),

- $\quad$ zvládnout sebeobsluhu, uplatňovat základní kulturně hygienické a zdravotně preventivní návyky (starat se o osobní hygienu, prijímat stravu a tekutinu, umět stolovat, postarat se o sebe a své osobní věci, oblékat se, svlékat, obouvat apod.), 
- zvládat jednoduchou obsluhu a pracovní úkony (postarat se o hračky, pomůcky, $\quad$ uklidit po sobě, udržovat pořádek, zvládat jednoduché úklidové práce, práce na zahradě apod.).

Pro dosahování očekávaných výstupů je jako vzdělávací prostředek uvedena vzdělávací nabídka, např.

- manipulační činnosti a jednoduché úkony s předměty, pomůckami, nástroji, náčiním, materiálem; činnosti seznamující děti s věcmi, které je obklopují a jejich praktickým používáním,

- konstruktivní a grafické činnosti,

- jednoduché pracovní a sebeobslužné činnosti voblasti osobní hygieny, stolování, oblékání, úklidu, úpravy prostředí apod.,

- činnosti relaxační a odpočinkové, zajišt'ující zdravou atmosféru a pohodu prostředí.

Voblasti Dítě a jeho psychika vpodoblasti Poznávací schopnosti a funkce, představivost a fantazie, myšlenkové operace jsou uvedené výstupy:

- postupovat a učit se podle pokynů a instrukcí,

- řšit problémy, úkoly a situace, myslet kreativně, předkládat „nápady“,

- nalézat nová řešení nebo alternativní $\mathrm{k}$ běžným,

- vyjadřovat svou představivost $\mathrm{a}$ fantazii $\mathrm{v}$ tvořivých činnostech (konstruktivních, výtvarných, hudebních, pohybových či dramatických) i ve slovních výpovědích $\mathrm{k}$ nim.

\section{Vzdělávací nabídka:}

- motivovaná manipulace s předměty, zkoumání jejich vlastností,

- spontánní hra, volné hry a experimenty s materiálem a předměty,

- námětové hry a činnosti,

- hry nejrůznějšího zaměření podporující tvořivost, představivost a fantazii (kognitivní, imaginativní, výtvarné, konstruktivní, hudební, taneční či dramatické aktivity),

- $\quad$ hry a praktické úkony procvičující orientaci v prostoru i v rovině apod.

V podoblasti city, sebepojetí a vůle jsou stanovené očekávané výstupy, které mají rozvíjet u dětí citlivý vztahu $\mathrm{k}$ živým bytostem, $\mathrm{k}$ prírodě $\mathrm{i} \mathrm{k}$ věcem

- těšit se $\mathrm{z}$ hezkých a př́jemných zážitků, z prrírodních i kulturních krás $\mathrm{i}$ setkávání se s uměním,

- zachytit a vyjádřit své prožitky (slovně, výtvarně, pomocí hudby, hudebně pohybovou, či dramatickou improvizací apod.)

\section{Vzdělávací nabídka:}

- spontánní hra,

- c cinnosti zajištujujicí spokojenost a radost, činnosti vyvolávající veselí a pohodu, 
- činnosti přiměřené sílám a schopnostem dítěte a úkoly s viditelným cílem a výsledkem, v nichž může být dítě úspěšné,

- př́ležitosti a hry pro rozvoj vůle, vytrvalosti a sebeovládání,

- $\quad$ výlety do okolí (do př́rody, návštěvy dětských kulturních akcí apod.)

Oblast dítě a společnost z pracovní výchovy obsahuje výstupy zaměřené

- zachycovat skutečnosti ze svého okolí a vyjadřovat své představy pomocí různých výtvarných dovedností a technik (kreslit, používat barvy, modelovat, konstruovat, tvořit $\mathrm{z}$ papíru, tvořit a vyrábět $\mathrm{z}$ různých jiných materiálů, z prŕrodnin aj.)

\section{Vzdělávací nabídka:}

- různorodé společné hry a skupinové aktivity (námětové hry, dramatizace, konstruktivní, a výtvarné projekty apod.) umožňující dětem spolupodílet se na jejich průběhu i výsledcích,

- přípravy a realizace společných zábav a slavností (oslavy výročí, slavnosti $\mathrm{v}$ rámci zvyků a tradic, sportovní akce, kulturní programy apod.)

- $\quad$ hry a praktické činnosti uvádějící dítě do světa lidí, jejich občanského života a práce (využívání praktických ukázek z okolí dítěte, tematické hry seznamující dítě $\mathrm{s}$ různými druhy zaměstnání, řemesel a povolání, s různými pracovními činnostmi a pracovními předměty, praktická manipulace s některými pomůckami a nástroji, provádění jednoduchých pracovních úkonů a činností apod.)

\section{Oblast dítě a svět}

- zvládat běžné činnosti a požadavky na dítě kladené i jednoduché praktické situace, které se doma a $\mathrm{v}$ mateřské škole opakují, chovat se přiměřeně a bezpečně doma i na veřejnosti (na ulici, na hřišti, v obchodě, u lékaře apod.)

- mít povědomí o širším společenském, věcném, přírodním, kulturním i technickém prostředí $\mathrm{i}$ jeho dění $\mathrm{v}$ rozsahu praktických zkušeností a dostupných praktických ukázek v okolí dítěte,

- mít povědomí o významu životního prostředí (př́rody i společnosti) pro člověka, uvědomovat si, že způsobem, jakým se dítě i ostatní v jeho okolí chovají, ovlivňují vlastní zdraví i životní prostředí,

- pomáhat pečovat o okolní životní prostředí (dbát o pořádek a čistotu, nakládat vhodným způsobem s odpady, starat se o rostliny, spoluvytváret pohodu prostředí, chránit př́rodu v okolí, živé tvory apod.)

\section{Vzdělávací nabídka:}

- prrirozené pozorování blízkého prostředí a života v něm, okolní prrírody, kulturních i technických objektů, vycházky do okolí, výlety,

- praktické užívání technických př́strojůn, hraček a dalších předmětů a pomůcek, se kterými se dítě běžně setkává, 
- $\quad$ praktické činnosti, na jejichž základě se dítě seznamuje s různými př́rodními i umělými látkami a materiály ve svém okolí a jejichž prostřednictvím získává zkušenosti $\mathrm{s}$ jejich vlastnostmi (praktické pokusy, zkoumání, manipulace $\mathrm{s}$ různými materiály a surovinami),

- ekologicky motivované hrové aktivity (ekohry),

- smysluplné činnosti přispívající $\mathrm{k}$ péči o životní prostředí a okolní krajinu, pracovní činnosti, pěstitelské a chovatelské činnosti, činnosti zaměřené $\mathrm{k}$ péči o školní prostředí, školní zahradu a blízké okolí. (RVP PV, 2005)

RVP PV stanovuje cíle a očekávané výstupy pro děti ukončující předškolní vzdělávání. Vzdělávací nabídka je formulovaná v obecné rovině. Předškolní pedagogové si vytváŕejí vlastní školní vzdělávací programy s ohledem na podmínky konkrétní školy a třídní plány, v nichž je zohledněna nejenom věková skupiny dětí, ale i zájmy a potřeby jednotlivých dětí.

Zde vidíme mnohdy neschopnost učitelek zakomponovat do vzdělávacích činností polytechnické vzdělávání jako zcela přirozenou součást práce mateřské školy.

Tab. 3 Hodnocení kurikula ve vybraných kritériích

\begin{tabular}{|l|l|l|}
\hline \multicolumn{1}{|c|}{ Kritéria } & \multicolumn{1}{|c|}{$\begin{array}{c}\text { Osnovy a programy } \\
\text { výchovné práce } \\
(\mathbf{1 9 4 5}-\mathbf{1 9 9 0 )}\end{array}$} & \multicolumn{1}{c|}{ RRV PV } \\
\hline Cíle & konkrétní úkoly & $\begin{array}{l}\text { cíle očekávané výstupy } \\
\text { formulované pouze rámcově }\end{array}$ \\
\hline $\begin{array}{l}\text { Struktura podle } \\
\text { věku }\end{array}$ & $\begin{array}{l}\text { ANO } \\
\text { zpočátku členění pro ml. a } \\
\text { st. děti } \\
\text { později: } \\
\text { 3-4leté, } \\
\text { 4-5leté, } \\
\text { 5-6leté }\end{array}$ & $\begin{array}{l}\text { NE } \\
\text { výstupy formulované pro konec } \\
\text { předškolního období }\end{array}$ \\
\hline Obsah & složky výchov & \\
\hline $\begin{array}{l}\text { Vzdělávací } \\
\text { aktivity }\end{array}$ & $\begin{array}{l}\text { konkrétní činnosti a } \\
\text { aktivity }\end{array}$ & výchovné oblasti \\
\hline
\end{tabular}

\section{Závěr}

RVP PV přinesl zcela nový způsob projektování vzdělávací práce, který klade dalece větší nároky na profesní kompetence pedagoga. Dř́ivější programy učitelkám přímo ukládaly konkrétní úkoly a činnosti jednoznačně zaměřené na všechny složky výchovy, tedy i na výchovu pracovní. Lze konstatovat, že úroveň pracovní výchovy byla velmi dobrá. Její zatíženost ideologií a mnohdy její nesprávné pojetí učitelkami, vedlo $\mathrm{k}$ převaze řízených činností a opomíjení tak potřebných činností spontánních. Taktéž jsme se setkávali se zařazováním pro děti nevhodných ideologických témat, vzdálených od možnosti chápání dítěte předškolního věku. Současné kurikulum tvoří pouhý rámec, učitelka musí být schopna projektovat rozvoj celé osobnosti dítěte a žádnou oblast 
neopomíjet, což od ní vyžaduje systematický a promyšlený př́stup. Uvedená skutečnost se týká i polytechnického vzdělávání. Učitelka si musí být vědoma, že i když není tato oblast uváděná samostatně, ale jako soubor požadavků pro celkový rozvoj dítěte, což se jí ne vždy daří. Polytechnické vzdělávání učitelka realizuje v průběhu celého dne, a to v rámci spontánních i řízených činností. Rozvíjí děti na základě jejich dokonalé znalosti. Jako významnou motivaci využívá dětské zájmy, na jejichž základě připravuje vzdělávací nabídku a podnětné prostředí. Využívá dětské zvídavosti, zájem o konstruování, experimentování apod. Dítě je nutné rozvíjet všestranně a neopomíjet žádnou ze vzdělávacích oblastí, aby nedocházelo, v nichž má polytechnické vzdělávání své významné místo.

To vše od předškolního pedagoga vyžaduje vysoce kvalifikovaný př́stup ke každému dítěti a porozumění koncepci současného kurikula.

\section{Literatura}

Komenský, J. A. (2007) Informatorium školy mateřské. Praha: ACADEMICA.

Šmelová, E. (2004) Mateřská škola teorie a praxe I. Olomouc: UP.

Metodika výchovné práce v jeslích a v mateřských školách. (1967). Praha: SPN.

Metodika pracovní výchovy v mateřské škole. (1979). Praha: SPN.

Osnovy výchovné práce pro mateřské školy. (1961). Praha: SPN.

Program výchovné práce pro jesle a mateřské školy. (1978). Praha: SPN.

Program výchovné práce pro jesle a mateřské školy. (1984). Praha: SPN.

Rámcový program pro předškolní vzdělávání. (2004). Praha: NÚV. 